5. Miatech J, Hughes JH, McCarty DK, Stagg MP. Ibrutinib-associated cardiac tamponade with concurrent antiplatelet therapy. Case Rep Hematol 2020;2020:4282486.

6. Shatzel JJ, Olson SR, Tao DL, McCarty OJ, Danilov AV, DeLoughery TG. Ibrutinib-associated bleeding; pathogenesis, management, and risk reduction strategies. J Thromb Haemost 2017;15:835-847.
7. Kamel $S$, Horton L, Ysebaert L, Levade M, Burbury K, Tan S, Cole-Sinclair M, Reynolds J, Filshie R, Schischka S, Khot A, Sandhu S, Keating MJ, Nandurkar $H$, Tam CS. Ibrutinib inhibits collagen-mediated but not ADP-mediated platelet aggregation. Leukemia 2015;29:783-787.

\title{
Cutaneous Anaplastic Large-Cell Lymphoma with Dramatic Response to Brentuximab Vedotin
}

\author{
Brentuximab Vedotine Dramatik Yanıtı Kutanöz Anaplastik Büyük Hücreli Lenfoma
}

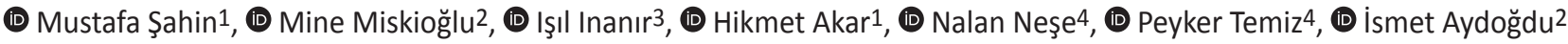 \\ ${ }^{1}$ Celal Bayar University Faculty of Medicine, Department of Internal Medicine, Manisa, Turkey \\ ${ }^{2}$ Celal Bayar University Faculty of Medicine, Department of Hematology, Manisa, Turkey \\ ${ }^{3}$ Celal Bayar University Faculty of Medicine, Department of Dermatology, Manisa, Turkey \\ ${ }^{4}$ Celal Bayar University Faculty of Medicine, Department of Patology, Manisa, Turkey
}

\section{To the Editor,}

Cutaneous lymphomas account for 5\% of non-Hodgkin lymphomas (NHLs). With 75\% of skin lymphomas originating from T-cells, CD30+ anaplastic large-cell NHL (ALCL) is the second most common type after mycosis fungoides. In treatment, excision and radiotherapy are the first options for single lesions, but systemic treatment is required for multiple ones. Brentuximab vedotin (BV) is an antibody-drug conjugate composed of a CD30-directed monoclonal antibody and monomethyl auristatin E. Recently, it has been used in the treatment of Hodgkin lymphoma and chemotherapy-resistant ALCL $[1,2,3]$.

An 84-year-old woman presented to the dermatology department with an erythematous plaque below the right eye, which had been present for 3 months. A round and firm nodule of $5 \mathrm{~cm}$ was also observed on the left breast. The mammography was consistent with a BI-RADS 5 lesion. The histopathological diagnoses were cutaneous ALCL for the facial lesions and invasive ductal carcinoma for the breast nodule. She declined treatment for both.

Three months thereafter, she was admitted with an ulcerative infiltration of the entire right side of the face, invading the right side of the frontal area (Figure 1). She also had weakness and loss of appetite. Hematological and biochemical parameters including lactate dehydrogenase were normal other than hemoglobin of $11.2 \mathrm{~g} / \mathrm{dL}$, and bone marrow biopsy results were normocellular. positron emission tomography-computed tomography (PET/CT) showed involvement of the right side of the face, left breast, and right cervical and mediastinal lymph nodes, with millimetric skin lesions of the whole body, especially in the right femur. The

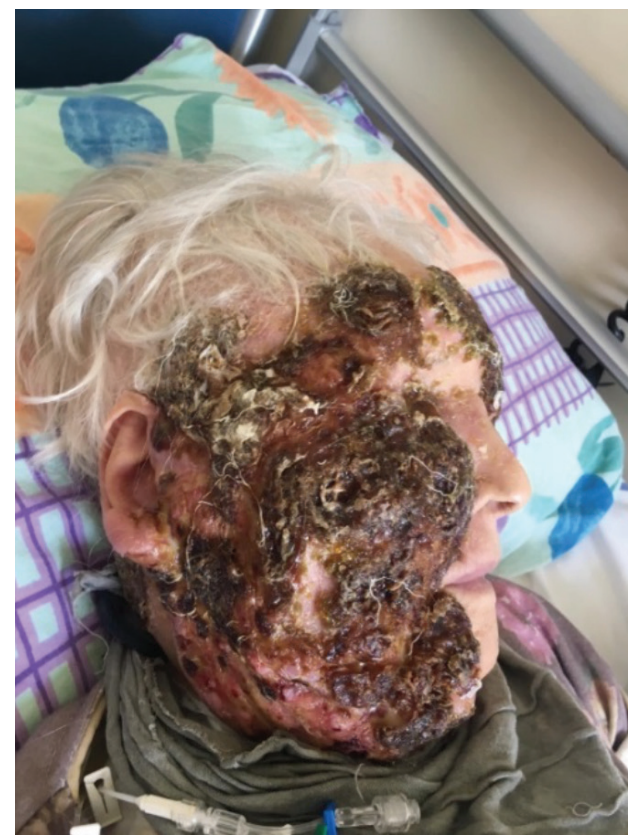

Figure 1. Before treatment. 
involvements other than the face were thought to be related to breast cancer, but this could not be confirmed by biopsy. The patient again did not accept surgery or other treatments for invasive ductal carcinoma.

Due to advanced age and frailty, combination chemotherapy was considered unsuitable, so BV monotherapy was administered at a dose of $1.8 \mathrm{mg} / \mathrm{kg}$ every 21 days for four cycles. Anastrozole was also added according to the recommendations of medical oncology. The facial lesions regressed significantly after the first cycle and disappeared after the fourth one, and up to 50\% reduction in the breast mass was observed. In PET/CT, although the involvement of the cervical, supraclavicular, and thoracic lymph nodes continued, the lesions in the skin, breast, and femur had disappeared. These findings suggested primary cutaneous $A L C L$, but it is difficult to draw a definitive conclusion. It is thought that the regression in the breast lesion might be related to the anastrozole taken with brentuximab. There was no BV-related toxicity and daily activities improved (Figures 2 and 3).

There are several reports presenting the effectiveness of BV treatment for ALCL $[4,5,6]$. The ECHELON-2 (a BV-containing regimen) and ALCANZA (BV alone) studies showed higher rates of progression-free survival than regimens without BV for CD30+ cutaneous T-cell lymphoma patients $[5,6]$. As in our case, it may be a good option to use BV as firstline monotherapy for cases not suitable for combined chemotherapy $[1,2,3]$.

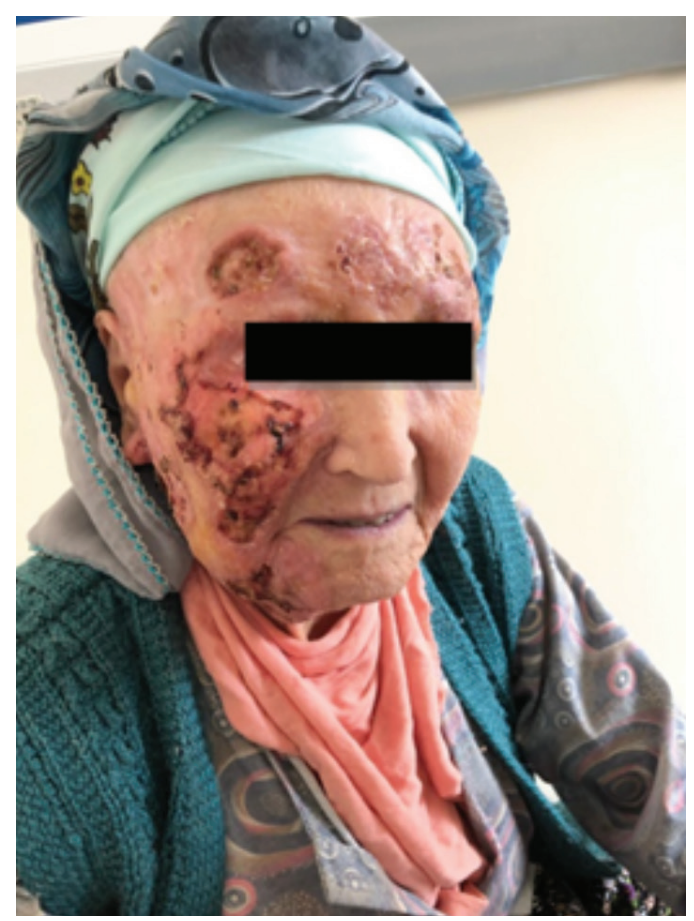

Figure 2. After the first cycle.

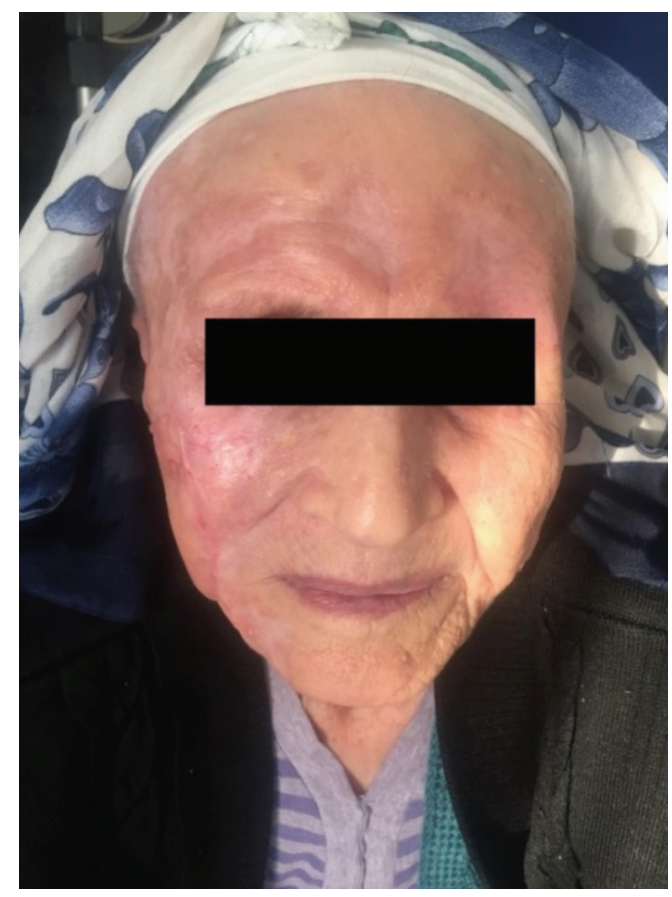

Figure 3. After the fourth cycle.

Keywords: Cutaneous anaplastic large cell lymphoma, Brentuximab, Monotherapy, Breast cancer

Anahtar Sözcükler: Kutanöz anaplastik büyük hücreli lenfoma, Brentuximab, Monoterapi, Meme kanseri

\section{Ethics}

Informed Consent: Obtained.

\section{Authorship Contributions}

Concept: M.M., M.Ş.; Design: M.Ş., M.M.; Data Collection or Processing: M.S., M.M., H.A.; Analysis or Interpretation: M.M., M.Ş.; Literature Search: M.Ş.; Writing: M.M., M.Ş., I.I.; Critical Review: I.A., M.M., I.Ş.

Conflict of Interest: No conflict of interest was declared by the authors.

Financial Disclosure: The authors declared that this study received no financial support.

\section{References}

1. O'Connor OA, Marchi E, Bhagat G, Coradini P, Guitart J, Rosen ST. T-cell lymphomas. In: Hoffman R, Benz EJ Jr, Silberstein LE, Heslop HE, Weitz JI, Anastasi J (eds). Hematology Basic Principles and Practice (6th Edition). Philadelphia, Elsevier Saunders, 2013.

2. Willemze $R$, Hodak E, Zinzani PL, Specht L, Ladetto M; ESMO Guidelines Working Group. Primary cutaneous lymphomas: ESMO Clinical Practice Guidelines for diagnosis, treatment and follow-up. Ann Oncol 2013;24:149154. 
3. Pro $B$, Advani R, Brice $P$, Bartlett NL, Rosenblatt JD, Illidge $T$, Matous J, Ramchandren $R$, Fanale $M$, Connors JM, Yang $Y$, Sievers EL, Kennedy DA, Shustov A. Brentuximab vedotin (SGN-35) in patients with relapsed or refractory systemic anaplastic large-cell lymphoma: results of a phase II study. J Clin Oncol 2012;30:2190-2196.

4. Onaka T, Kitagawa T, Kawakami C, Yonezawa A. Improvement of cutaneous anaplastic large cell lymphoma by brentuximab vedotin monotherapy. Turk J Hematol 2018;35:135-136.

5. Horwitz $S$, O'Connor OA, Pro B, Illidge $T$, Fanale M, Advani R, Bartlett NL, Christensen JH, Morschhauser F, Domingo-Domenech E, Rossi G, Kim WS, Feldman T, Lennard A, Belada D, Illés Á, Tobinai $K$, Tsukasaki $K$, Yeh SP, Shustov A, Hüttmann A, Savage KJ, Yuen S, Iyer S, Zinzani PL, Hua Z,
Little M, Rao S, Woolery J, Manley T, Trümper L; ECHELON-2 Study Group. Brentuximab vedotin with chemotherapy for CD30-positive peripheral T-cell lymphoma (ECHELON-2): a global, double-blind, randomised, phase 3 trial. Lancet 2019;393:229-240.

6. Prince HM, Kim YH, Horwitz SM, Dummer R, Scarisbrick J, Quaglino P, Zinzani PL, Wolter P, Sanches JA, Ortiz-Romero PL, Akilov OE, Geskin L, Trotman J, Taylor K, Dalle S, Weichenthal M, Walewski J, Fisher D, Dréno B, Stadler R, Feldman T, Kuzel TM, Wang Y, Palanca-Wessels MC, Zagadailov E, Trepicchio WL, Zhang W, Lin HM, Liu Y, Huebner D, Little M, Whittaker S, Duvic M; ALCANZA Study Group. Brentuximab vedotin or physician's choice in CD30positive cutaneous T-cell lymphoma (ALCANZA): an international, openlabel, randomised, phase 3, multicentre trial. Lancet 2017;390:555-566.

๑Copyright 2021 by Turkish Society of Hematology

Turkish Journal of Hematology, Published by Galenos Publishing House

\title{
A Promising New Therapy of Oral Ixazomib Without Rituximab for Waldenstrom Macroglobulinemia
}

\author{
Waldenström Makroglobulinemisinde Rituksimab İçermeyen Yeni Umut Verici Oral \\ Iksazomib Tedavisi
}

\author{
(D) Wanlu Ma1, (D) Jiawei Zhao², (D) Lu Zhang³ \\ 1 Peking Union Medical College Hospital, Chinese Academy of Medical Sciences and Peking Union Medical College, Department of Endocrinology, \\ Beijing, China \\ 2 Peking Union Medical College Hospital, Chinese Academy of Medical Sciences and Peking Union Medical College, Department of Rheumatology, \\ Beijing, China \\ ${ }^{3}$ Peking Union Medical College Hospital, Chinese Academy of Medical Sciences and Peking Union Medical College, Department of Hematology, \\ Beijing, China
}

\section{To the Editor,}

A 73-year-old woman was admitted with complaints of low fever, fatigue, shortness of breath, and edema of the lower extremities. Hemoglobin $(\mathrm{Hb})$ and platelets (PLTs) were 76-93 g/L (normal range: $110-160 \mathrm{~g} / \mathrm{L}$ ) and $75-103 \times 109 / \mathrm{L}(100-300 \times 109 / \mathrm{L})$, respectively. Serum protein electrophoresis indicated that $M$ protein and immunoglobulin $\mathrm{M}$ were elevated to $8.6 \mathrm{~g} / \mathrm{L}$ and $11.9 \mathrm{~g} / \mathrm{L}(0.4-2.3 \mathrm{~g} / \mathrm{L})$. Blood immunofixation electrophoresis also exhibited positive immunoglobulin M (IgM)к. Computed tomography (CT) scans revealed multiple enlarged lymph nodes in the mediastinum, mesentery, neck, underarms, and groin with pericardial and pleural effusion and splenomegaly (Figures $1 \mathrm{~A}$ and $1 \mathrm{C}$ ). A bone marrow smear revealed $7.5 \%$ lymphocytic plasma cells, whose immune phenotypes were consistent with Waldenstrom macroglobulinemia (WM). Furthermore, L265P mutation in MYD88 was detected in the bone marrow and pleural effusion. Accordingly, WM was diagnosed and the RCD regimen (rituximab, dexamethasone, cyclophosphamide) was given for 2 cycles, but her PLTs quickly decreased to $15 \times 109 / \mathrm{L}$ with petechiae during the infusion of rituximab, probably due to rituximab-induced thrombocytopenia [1]. Two weeks later, PLTs gradually increased to $80 \times 10^{9} / \mathrm{L}$, but $\mathrm{Hb}$ remained at $54 \mathrm{~g} / \mathrm{L}$ and $\mathrm{M}$ protein did not decrease. A CT scan did not show any reduction of pericardial or pleural effusion. Meanwhile, a new-onset femoral neck fracture prevented her from coming to the hospital for a bortezomib-based regimen and economic status restricted her from usage of ibrutinib and ICD (ixazomib, dexamethasone, cyclophosphamide). Therefore, an oral treatment regimen was given for 1 cycle followed by 5 cycles of ID regimen (ixazomib, dexamethasone) due to neutropenia possibly induced by cyclophosphamide. Strikingly, Hb rose back to $125 \mathrm{~g} / \mathrm{L}$ and PLTs remained stable at $155 \times 109 / \mathrm{L}$. M protein fell back to $0.6 \mathrm{~g} / \mathrm{L}$. A CT scan showed normal size of multiple lymph nodes and absence of pericardial and pleural effusion (Figures 1B and 1D). The patient achieved very good partial response (VGPR) after 6 cycles of ixazomib-based regimen and remained in VGPR without maintenance for 1 year. 